\title{
A high mannose concentration is well tolerated by colorectal adenocarcinoma and melanoma cells but toxic to normal human gingival fibroblast: an in vitro investigation
}

\author{
Muhammad Alif Mazlan ${ }^{1,2}$, Muhammad Lokman Md. Isa ${ }^{1,2^{*}}$ (D) and Moustafa Ibrahim ${ }^{3}$
}

\begin{abstract}
Background: The primary cause of cancer is gene mutation which allows the growth of abnormal and damaged cells. Nutrition is one of the key factors that either increases or decreases the risk of cancer. Mannose has been found in many fruits such as oranges, apples and berries. Mannose has been linked to increase the risk factors or potential therapeutic for cancers. However, insufficient information is available on the effects of high mannose concentration on the normal and cancer cell lines. This study aimed to evaluate the viability patterns of human cancer and normal cell lines treated with mannose. Human gingival fibroblast (HGF), skin malignant melanoma (A375) and colorectal adenocarcinoma (HT29) cell lines were cultured and treated with additional mannose in three respective concentrations: $1 \mathrm{mg} / \mathrm{ml}, 5 \mathrm{mg} / \mathrm{ml}$ and $10 \mathrm{mg} / \mathrm{ml}$. Then, cell viability was measured using an MTT (3-(4,5dimethylthiazol-2-yl)-2,5-diphenyl tetrazolium bromide)-assay.

Results: The HGF cells' percentage pattern of viability showed a rapid decline of nearly $95 \%$ on the third day of treatment. A375 cells were able to survive in high mannose condition as the cell viability percentage was at the highest value on Day 5. Meanwhile, HT29 cells showed declining cell viability pattern when treated with mannose. The data exhibited significance; the $p$ value was less than 0.001 .

Conclusions: High mannose concentration can be toxic to HGF. In addition, A375 is adaptive to mannose at all concentrations in which it shares the same pattern with the untreated group. However, the cell viability pattern for HT29 cell is declining.
\end{abstract}

Keywords: In vitro technique, Fibroblasts, Adenocarcinoma, Malignant melanoma, Mannose, Cancer

\footnotetext{
* Correspondence: lokman@iium.edu.my

${ }^{1}$ Department of Basic Medical Sciences for Nursing, International Islamic

University Malaysia, Jalan Sultan Ahmad Shah, Bandar Indera Mahkota, 25200

Kuantan, Pahang, Malaysia

${ }^{2}$ IIUM Molecular and Cellular Biology Research Cluster (iMoleC), International

Islamic University Malaysia, Jalan Sultan Ahmad Shah, Bandar Indera

Mahkota, 25200 Kuantan, Pahang, Malaysia

Full list of author information is available at the end of the article
}

\section{Springer Open}

(c) The Author(s). 2020 Open Access This article is licensed under a Creative Commons Attribution 4.0 International License, which permits use, sharing, adaptation, distribution and reproduction in any medium or format, as long as you give appropriate credit to the original author(s) and the source, provide a link to the Creative Commons licence, and indicate if changes were made. The images or other third party material in this article are included in the article's Creative Commons licence, unless indicated otherwise in a credit line to the material. If material is not included in the article's Creative Commons licence and your intended use is not permitted by statutory regulation or exceeds the permitted use, you will need to obtain permission directly from the copyright holder. To view a copy of this licence, visit http://creativecommons.org/licenses/by/4.0/. 


\section{Background}

Cancer is a multifactorial disease that could be the result from various factors including diet, lifestyle, environment, chemical and so forth [1]. However, the prime aetiology of cancer is gene mutation as it would lead to the production of abnormal or damaged cells. Physiologically, p53 is the tumour suppressor protein which plays an important role in arresting or eliminating abnormal and damaged cells [2]. Basically, the cell death would be due to autophagy, apoptosis or necrosis. Autophagy is a mechanism in which the cytoplasmic components are engulfed in double-membraned vesicles before the lysosome degrades the vesicles [3]. Apoptosis is defined as the process of cell shrinkage, DNA fragmentation and phagocytosis by macrophages or neighbouring cells [4]. Meanwhile, necrosis is a mode of cell death that results from the loss of integrity of the plasma membrane and the breakdown of organelles with the release of proteolytic enzymes which subsequently initiate the destruction of the surrounding cells and promote the inflammation [5]. In terms of cell death mechanism, apoptosis is better than necrosis as it avoids the trauma towards the neighbouring cells while necrosis increases the inflammation. Chronic inflammation is one of the risk factors that could lead to the formation of cancer [6]. Among cancer survivors, food that could contribute to inflammation need to be controlled.

Since a cancer survivor has the tendency to undergo the recurrence of cancer, it is very essential to manage the survivors of cancer in terms of dietary intake. Dietary factors have been recognized to have significant effects on increasing and decreasing the cancer risk [7]. The needs and metabolic physiology of cancer survivors might differ from normal people. A regimen of food could possibly be designed to avoid the recurrence of cancer among cancer survivors. For instance, one metaanalysis study had summarized the adherence to a highquality diet and healthy dietary pattern is inversely associated with the mortality of cancer survivors [8]. In order to develop this regimen, it is necessary to conduct scientific researches to understand the needs of either cancer patients or the survivors. For instance, it is compulsory to understand the behaviour and pattern of the cell lines when they are treated with monosaccharides.

The focus of this study was to observe the cell viability pattern of the normal and cancer cell lines when treated with mannose. Mannose is a sugar monomer of the aldohexose series of carbohydrates [9]. Commonly, mannose could be abundantly found in varieties of fruits such as apples, oranges and berries [10]. Mannose has been reported to play a vital role for the treatment of congenital disorder of glycosylation (CDG) as the mannose improved the protein glycosylation [11]. In addition, oral administration of mannose suppressed the immunopathology in models of autoimmune diabetes and airway inflammation [12]. However, high dosage of mannose could cause injury towards the kidneys [13]. Furthermore, the scientific evidence on the cell viability pattern of the normal and cancer cell lines that were treated with mannose is insufficient. The findings of this study will probably become a starting point to discover more about cancer and sugar which would eventually help the physician by suggesting the cancer patients to avoid or reduce the intake of sugar derivatives that may increase the risk factor of getting cancer. It is a fact that our body needs sugar, but it is better to have options to choose sugar that is less favourable by cancer cells. In addition, the therapy for cancer could also be designed in the future by incorporating the most favourable monosaccharide with nanoparticles. Herein, this study aimed to investigate the pattern of cell viability of normal and cancer cell lines when they are treated with mannose for therapeutic value.

\section{Methods}

Selection and preparation of normal and cancer cell lines The cell lines that were used in this study were normal human gingival fibroblast (HGF-1, ATCC CRL-2014, USA), human colorectal adenocarcinoma (HT-29, ATCC HTB-38, USA) and human malignant melanoma (A375, ATCC CRL-1619, USA). The cells were purchased from American Type Culture Collection (ATCC) in which the cells had undergone authentication and mycoplasma tests.

\section{Media preparation, optimization of concentration and treatment period}

In this study, complete media was used for the cellular growth. The complete media was formulated with Dulbecco's modified Eagle's medium (DMEM) (Nacalai Tesque, Japan) added with $10 \%$ of foetal bovine serum (FBS) (Himedia Laboratories Pvt Ltd, India) and 1\% of antibiotic (streptomycin and penicillin) (Himedia Laboratories Pvt Ltd., India). This complete media was used as the control. Meanwhile, the treatment groups were prepared by dissolving mannose in the complete media. The optimization of concentration and treatment period for in vitro stability studies was adapted and modified from Shahbuddin [14]. Mannose was diluted properly at three different concentrations which were $1 \mathrm{mg} / \mathrm{ml}, 5 \mathrm{mg} / \mathrm{ml}$ and $10 \mathrm{mg} / \mathrm{ml}$. Then, the mixture of mannose and complete media were sterilized by using the filter at $0.22 \mu \mathrm{m}$., Meanwhile, there were four different incubation periods (1, 3, 5 and 10 days) that were applied as a treatment parameter to investigate the effect of mannose on the cell viability of the tested cell lines. 


\section{Culturing the cells for testing}

The cells (HGF, A375 and HT29) were thawed and revived in $25-\mathrm{ml}$ culture flasks containing complete media and incubated in $\mathrm{CO}_{2}$ incubator at $37^{\circ} \mathrm{C}$ with $5 \% \mathrm{CO}_{2}$. The complete media were changed after 3 days of incubation to ensure that the nutrients were sufficient for cell growth and development. Once the cells had achieved $80 \%$ of confluency, the cells were dissociated for the cell viability test. The cell seeding was conducted prior to the cell viability test. The cell was counted by using haemocytometer with the ratio for the cells and trypan blue of one to one. Approximately, 1000 cells were aliquoted into 12 -well plate as an initial seeding. Then, the cells (HGF, A375 and HT29) were treated with $1 \mathrm{mg} / \mathrm{ml}, 5 \mathrm{mg} / \mathrm{ml}$ and $10 \mathrm{mg} / \mathrm{ml}$ of mannose. Meanwhile, the control group was treated with the complete media which did not contain mannose. After that, the treated cells were incubated at four incubation periods (1, 3, 5 and 10 days). The fresh media of the control and treatment groups were changed every three days of incubation to ensure the nutrient was sufficient. The cell lines underwent the cell viability test once the incubation period was completed.

Viability test by the MTT (3-(4,5-dimethylthiazol-2-yl)-2,5diphenyl tetrazolium bromide) assay

MTT assay was conducted as a colourimetric technique to assess the cell metabolic activity. The viable cell number is reflected from the mitochondrial activity through the oxidoreduction reaction [15]. The treated cell lines in the well plate were washed with phosphate buffer saline (PBS) before the MTT reagent (Nacalai Tesque, Japan) was added. Twenty microlitres of MTT reagent with a concentration of $0.5 \mathrm{mg} / \mathrm{ml}$ was dispensed into each well and incubated for at least $2 \mathrm{~h}$. Subsequently, after $2 \mathrm{~h}$ of incubation, the MTT reagent was aspirated and $200 \mu$ of dimethyl sulfoxide (DMSO) was added to solubilize the formazan crystals. The absorbance was measured with microplate spectrophotometer (Tecan Trading AG, Switzerland) under a wavelength of 450 $\mathrm{nm}$. All the cell viability processes were treated as a light-sensitive process and wrapped with aluminium foil.

\section{Data analysis}

The Statistical Package for the Social Sciences (SPSS) software version 22 was used to analyse the data obtained from this study. The data were collected by triplicating for each of the treatments at two independent experiments. The treated groups with mannose were compared with the control group. The values were expressed as the standard error of the mean \pm standard deviation. The one-way ANOVA statistical test was conducted in this study. $p$ value $\leq 0.05$ was considered significant.

\section{Results}

This study was conducted to evaluate the role of mannose on the viability pattern, the cell lines (human gingival fibroblast (HGF), skin malignant melanoma (A375) and colorectal adenocarcinoma (HT29)) that were treated with mannose at three different concentrations $(1 \mathrm{mg} / \mathrm{ml}, 5 \mathrm{mg} / \mathrm{ml}$ and $10 \mathrm{mg} / \mathrm{ml})$. The groups that were treated with mannose were compared with the control group (complete media). The graph portrays the cell viability pattern of HGF cells that were treated with mannose at three different concentrations (Fig. 1). Overall, the groups that were treated with mannose had caused the cell viability pattern of the HGF cells to decline after

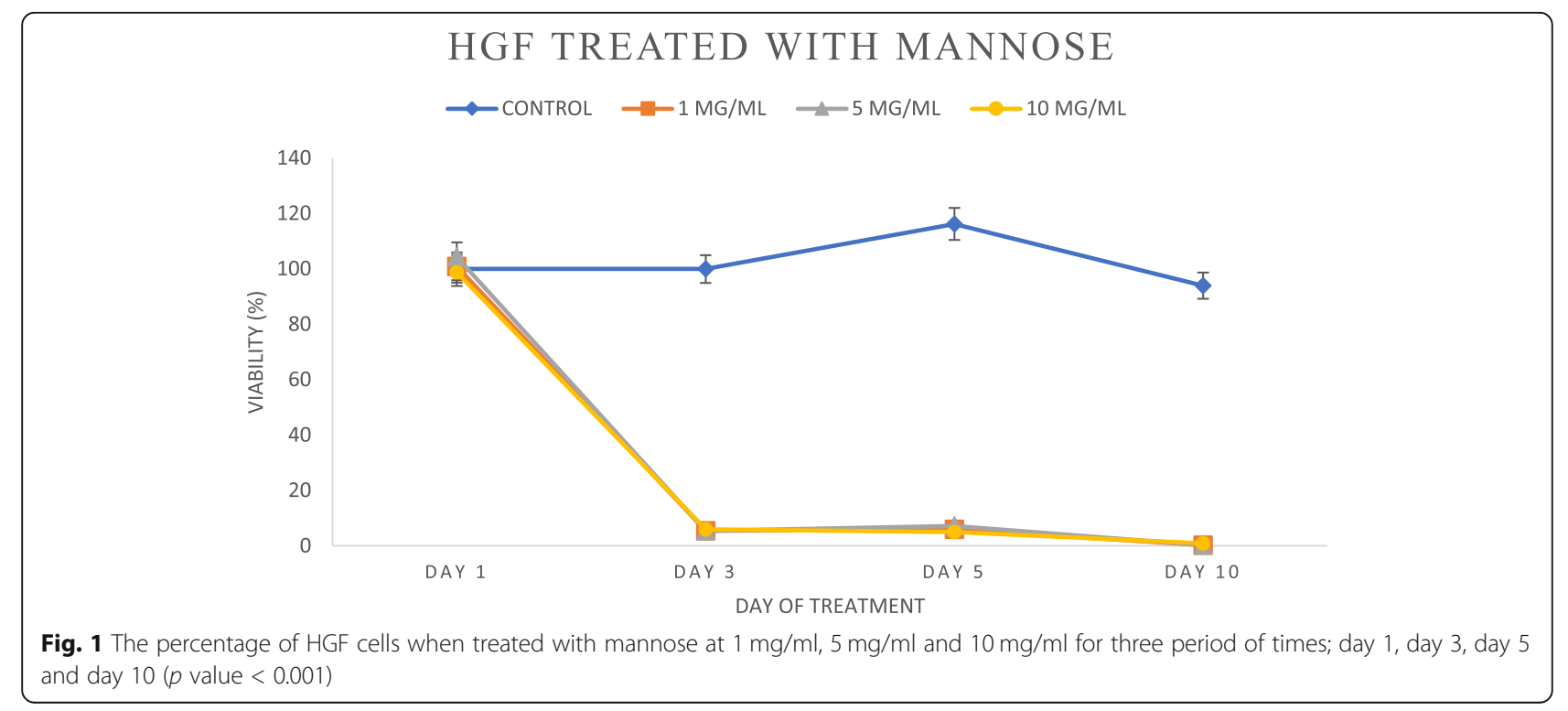




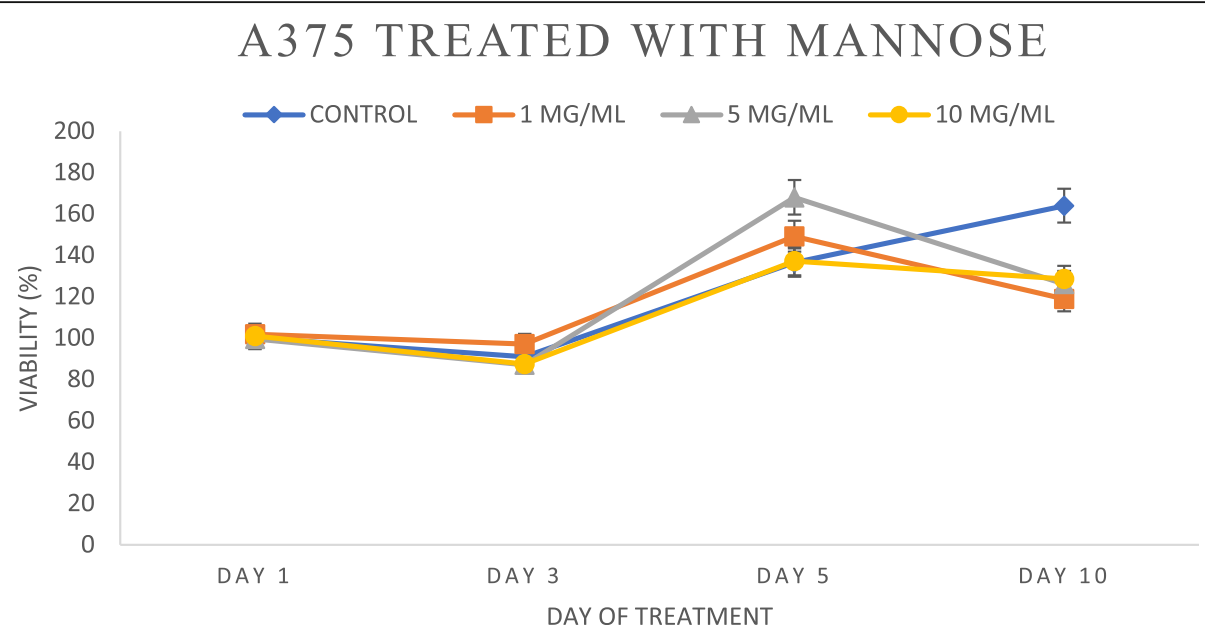

Fig. 2 The percentage of A375 cells when treated with mannose at $1 \mathrm{mg} / \mathrm{ml}, 5 \mathrm{mg} / \mathrm{ml}$ and $10 \mathrm{mg} / \mathrm{ml}$ for three period of times; day 1 , day 3 , day 5 and day 10 ( $p$ value $<0.001)$

day 1 at all concentrations $(1 \mathrm{mg} / \mathrm{ml}, 5 \mathrm{mg} / \mathrm{ml}$ and 10 $\mathrm{mg} / \mathrm{ml})$. At day 3 , the treatment groups $(1 \mathrm{mg} / \mathrm{ml}$ and 5 $\mathrm{mg} / \mathrm{ml}$ ) declined dramatically from day 1 . However, the cell viability of these groups slightly increased at day 5 and continued to decline until day 10. Meanwhile, the HGF cells that were treated with $10 \mathrm{mg} / \mathrm{ml}$ mannose experienced rapid decline after day 1 until day 10 .

The plotted graph depicts the cell viability pattern of A375 cells which were treated with mannose with the respective concentrations (Fig. 2). Based on the plotted graph, the cell viability pattern of A375 cells shows the potential to survive when treated with mannose. The pattern of the cell viability of all groups that were treated with mannose showed reduction after day 1 . From day 3 , the cell viability was increasing until day 5 and then decreased on day 10. For the control group, after day 1 , the cell viability of A375 cells showed slightly declining pattern which then continued to increase from day 3 until day 10 .

The graph illustrates the cell viability of the HT29 cells that were treated with mannose at three different concentrations (Fig. 3). In terms of cell viability pattern, all groups that were treated with mannose distributed similar pattern which is a dramatic declining from day 1 until day 3. Then, the groups showed slight increment from day 3 to day 5 . Finally, the cell viability of the treatment groups continued to decline until day 10. In contrast, the HT29 cells that were treated with complete media (control group) showed a different pattern of cell viability. The HT29 cells extremely increased from day 1 until day 5 of the incubation period. However, the cells started to decline from day 5 until day 10 .

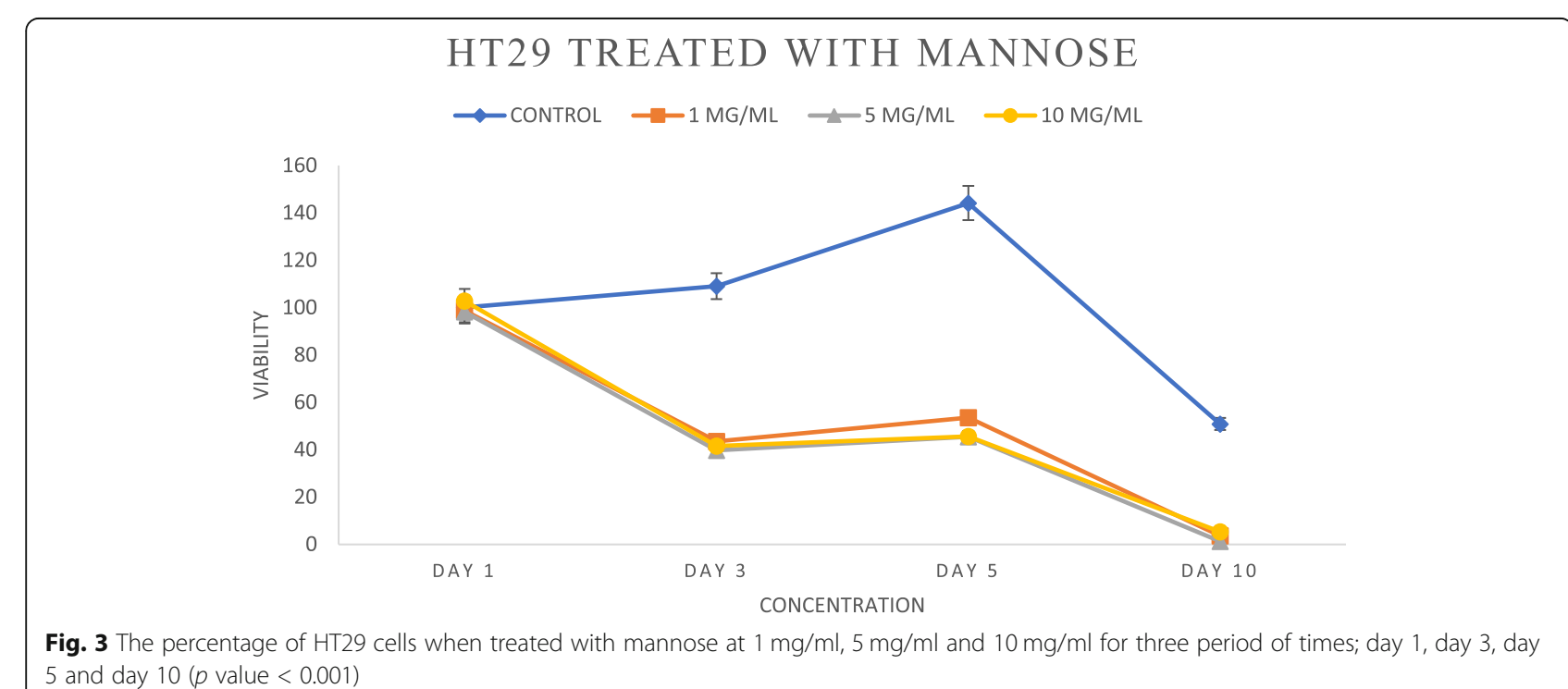


Table 1 One-way ANOVA table

\begin{tabular}{|c|c|c|c|c|c|}
\hline & Sum of squares & Df & Mean square & $F$ & $p$ value \\
\hline \multicolumn{6}{|l|}{ HGF-mannose } \\
\hline Between groups & 0.005 & 15 & $<0.001$ & 8.308 & $<0.001$ \\
\hline Within groups & 0.005 & 128 & $<0.001$ & & \\
\hline Total & 0.011 & 143 & & & \\
\hline \multicolumn{6}{|l|}{ A375-mannose } \\
\hline Between groups & 67.000 & 15 & 4.467 & 50.277 & $<0.001$ \\
\hline Within groups & 41.223 & 464 & 0.089 & & \\
\hline Total & 108.223 & 479 & & & \\
\hline \multicolumn{6}{|l|}{ HT29-mannose } \\
\hline Between groups & 6.353 & 15 & 0.424 & 180.266 & $<0.001$ \\
\hline Within groups & 1.062 & 452 & 0.002 & & \\
\hline Total & 7.415 & 467 & & & \\
\hline
\end{tabular}

The results of ANOVA are significant with the values of all data were less than 0.05 which are considered as significant (Table 1).

\section{Discussion}

The genetic changes that allow the growth of abnormal cells would subsequently lead to cancer formation because of abundant of damaged cells in the body system. From the findings, the cell viability of the normal cell line that was treated with mannose at different concentrations continued to reduce from day 1 and onwards of the incubation. Meanwhile, the cancer cell lines (A375 and HT29) that were treated with the mannose in vitro showed the capability to adapt and survive. The genetic between the normal and cancer cell lines play an important role for the metabolism of mannose.

Mannose's toxicity is due to the shortage of mannose phosphate isomerase which results in the accumulation of mannose-6-phosphate [16]. The mannose-6-phosphate is the result of the phosphorylation of mannose by glucomannokinase [17]. In addition, mannose toxicity leads to the depletion of adenosine triphosphate (ATP), a source of energy [18]. Therefore, normal HGF cells could not undergo the replication as the source of the energy is depleted. In addition, by-products of the mannose metabolism process such as reactive oxygen species (ROS) could also potentially cause the cell death of normal HGF cells. It has been reported that free radicals such as ROS could induce oxidative stress, a condition that would subsequently lead to cell death [19].

Some studies have proven that mannose could help in treating cancer. For instance, one study reported that mannose causes growth retardation in some tumour types in vitro, and intensifies the cell death in response to major forms of chemotherapy [20]. In addition, mannose is beneficial in treating urinary tract infections [21]. The mannose binds to the $E$. coli which are then discharged in the form of urine [22]. Chronic E. coli infection might play a role in the development of bladder cancer [23]. The infection causes the activation of nuclear factor kappa light chain enhancer of activated $B$ cells (NF-kB) pathway resulting in the inhibition of apoptosis and increases the inflammation [24]. Therefore, the survivability of the cancer cells would be due to the activation of the NF-kB mechanism which blocks the apoptosis pathway.

On the other hand, it has been reported that among diabetic patients, mannose has the potential to enhance diabetic complications as mannose glycated protein five times better than glucose [10]. Glycation process would lead to the production of advance glycation end products (AGEs). AGEs are collective name given to proteins, lipids and nucleic acids that undergo irreversible modification by reducing sugars or sugar-derived products [25]. It has been reported that the AGEs and AGE receptors interaction would stimulate the growth of human pancreatic cancer via the autocrine induction-derived growth factor-B [26]. Another study also reported that AGEs triggered the growth and migration of culture human melanoma cells [27]. AGEs have been reported to have the capability to mimic hormones or regulate their receptors mechanism at DNA level [28]. Therefore, the accumulation of these AGEs would interfere with normal physiological condition.

One of the limitations in this study is that only three types of cell lines were used. It would be better if more types of cancer and normal cell lines undergo the cell viability testing in order to understand the effect of mannose on the cell lines. In addition, the metabolites that were associated to cause cell death among the cell lines were not tested. Therefore, in the future, a study to detect the metabolites that enable the cell death or the ability to survive would benefit in developing diagnostic and therapeutic procedures for cancer. 


\section{Conclusions}

In conclusion, high mannose concentration caused the cell viability of normal human gingival fibroblast (HGF) to rapidly decline since day 1 of treatment. The skin malignant melanoma (A375) and colorectal adenocarcinoma (HT29) have the potential to adapt to the high mannose condition. Based on the cell viability pattern showed by the A375 cell line, the cells displayed a similar pattern with the control group. Meanwhile, the cell viability pattern of the HT29 cell line that was treated with mannose showed a declining pattern. This could indicate that mannose could possibly help in combating the colorectal adenocarcinoma cell line. Therefore, the findings of this study suggest that mannose has the potential to be one of the alternatives of source energy among colorectal adenocarcinoma cancer patients. Nevertheless, further research still needs to be conducted in order to evaluate the efficiency of mannose in treating colorectal adenocarcinoma.

\section{Abbreviations}

A375: Skin malignant melanoma; AGE: Advance glycation end product; ANOVA: Analysis of variance; ATCC: American Type Culture Collection; ATP: Adenosine triphosphate; CDG: Congenital disorder of glycosylation; $\mathrm{CO}_{2}$ : Carbon dioxide; DMEM: Dulbecco's modified Eagle's medium; DMSO: Dimethyl sulfoxide; DNA: Deoxyribonucleic acid; FBS: Foetal bovine serum; HGF: Human gingival fibroblast; HT29: Colorectal adenocarcinoma; MTT: 3-(4,5-dimethylthiazol-2-yl)-2,5-diphenyl tetrazolium bromide; NFkB: Nuclear factor kappa light chain enhancer of activated B cells; PBS: Phosphate buffer saline; ROS: Reactive oxygen species; SPSS: Statistical Package for the Social Sciences

\section{Acknowledgements}

This research was supported by the International Islamic University Malaysia with grant number FRGS15-253-0494. Therefore, the authors would like to thank the International Islamic University Malaysia (IIUM) especially the IIUM Molecular and Cellular Biology Research Cluster for providing the necessary help to conduct this study.

\section{Authors' contributions}

MAM had assembled the data and drafted the article for publication. MLM had provided the materials and important contents for the article. MI had contributed in terms of emphasizing the methods that were used in this study. All authors designed the concept for the project and worked together to analyse and interpret the data and approved the final manuscript.

\section{Funding}

The findings of this study have been funded by International Islamic University Malaysia with grant number FRGS15-253-0494. The fund was used to purchase the necessary materials for the sake of this study.

\section{Availability of data and materials}

All data generated or analysed during this study are included in this published article (at 'Results' section)

Ethics approval and consent to participate

Not applicable

\section{Consent for publication}

Not applicable

\section{Competing interests}

The authors declare there is no competing interest.

\section{Author details}

${ }^{1}$ Department of Basic Medical Sciences for Nursing, International Islamic University Malaysia, Jalan Sultan Ahmad Shah, Bandar Indera Mahkota, 25200 Kuantan, Pahang, Malaysia. ${ }^{2}$ IUUM Molecular and Cellular Biology Research

Cluster (iMoleC), International Islamic University Malaysia, Jalan Sultan Ahmad Shah, Bandar Indera Mahkota, 25200 Kuantan, Pahang, Malaysia. ${ }^{3}$ Department of Physics, Faculty of Science, Benha University, Benha 13518, Egypt.

Received: 3 August 2020 Accepted: 3 November 2020

Published online: 28 November 2020

\section{References}

1. Wu S, Zhu W, Thompson P, Hannun YA (2018) Evaluating intrinsic and nonintrinsic cancer risk factors. Nat Commun 9:3490 https://doi.org/10.1038/ s41467-018-05467-z

2. Baumann K (2012) Multitasking p53 promotes necrosis. Nat Rev Mol Cell Biol 13:480-481 https://doi.org/10.1038/nrm3401

3. Jacomin AC, Gul L, Sudhakar P, Korcsmaros T, Nezis IP (2018) What we learned from big data for autophagy research. Front Cell Dev Biol 6:92 https://doi.org/10.3389/fcell.2018.00092

4. Miyamoto SD, Stauffer BL (2017) Sucharov CC (2017) Chapter 3 - Molecular pathways in cardiomyopathies. In: Jefferies JL, Blaxall BC, Robbins J, Towbin JA (eds) Cardioskeletal myopathies in children and young adults. Academic Press, London, pp 39-64

5. Ying Y, Padanilam BJ (2016) Regulation of necrotic cell death: p53, PARP1 and cyclophilin D-overlapping pathways of regulated necrosis? Cell Mol Life Sci 73:2309-2324 https://doi.org/10.1007/s00018-016-2202-5

6. Aoki T, Narumiya S (2017) Prostaglandin E2-EP2 signaling as a node of chronic inflammation in the colon tumor microenvironment. Inflamm Regener 37:4 https://doi.org/10.1186/s41232-017-0036-7

7. Roomi MW, Niedzwiecki A, Rath M (2018) Scientific evaluation of dietary factors in cancer. J Nutri Med Diet Care 4:029 https://doi.org/10.23937/25723278.1510029

8. Schwedhelm C, Boeing H, Hoffmann G, Aleksandrova K, Schwingshackl L (2016) Effect of diet on mortality and cancer recurrence among cancer survivors: a systematic review and meta-analysis of cohort studies. Nutr Rev 74(12):737-748 https://doi.org/10.1093/nutrit/nuw045

9. Navarro DMDL, Abelilla JJ, Stein HH (2019) Structures and characteristics of carbohydrates in diets fed to pigs: a review. J Animal Sci Biotechnol 10:39 https://doi.org/10.1186/s40104-019-0345-6

10. Sharma V, Ichikawa M, Freeze HH (2014) Mannose metabolism: more than meets the eye. Biochem Biophys Res Commun 453(2):220-228 https://doi. org/10.1016/j.bbrc.2014.06.021

11. Chu J, Mir A, Gao N, Rosa S, Monson C, Sharma V, Steet R, Freeze HH, Lehrman MA, Sadler KC (2013) A zebrafish model of congenital disorders of glycosylation with phosphomannose isomerase deficiency reveals an early opportunity for corrective mannose supplementation. Dis Model Mech 6: 95-105 https://doi.org/10.1242/dmm.010116

12. Zhang D, Chia C, Jiao X, Jin W, Kasagi S, Wu R, Konkel JE, Nakatsukasa H, Zanvit P, Goldberg N, Chen Q, Sun L, Chen ZJ, Chen W (2017) D-mannose induces regulatory $T$ cells and suppresses immunopathology. Nat Med 23: 1036-1045 https://doi.org/10.1038/nm.4375

13. Zhuang A, Yap FYT, McCarthy D, Leung C, Sourris KC, Penfold SA, ThallasBonke V, Coughlan MT, Schulz BL, Forbes JM (2019) Globally elevating the AGE clearance receptor, OST48, does not protect against the development of diabetic kidney disease, despite improving insulin secretion. Sci Rep 9: 13664 https://doi.org/10.1038/s41598-019-50221-0

14. Shahbuddin M (2014) Development of konjac glucomannan hydrogels for wound healing. University of Sheffield, United Kingdom

15. He Y, Zhu Q, Chen M, Huang Q, Wang W, Li Q, Huang Y, Di W (2016) The changing 50\% inhibitory concentration (IC50) of cisplatin: a pilot study onthe artifacts of the MTT assay and the precise measurement of densitydependent chemoresistance in ovarian cancer. Oncotarget 7(43):7080370821 https://doi.org/10.18632/oncotarget.12223. Accessed 8 June 2020

16. DeRossi C, Bode L, Eklund EA, Zhang F, Davis JA, Westphal V, Wang L, Borowsky AD, Freeze HH (2006) Ablation of mouse phosphomannose isomerase (Mpi) causes mannose 6-phosphate accumulation, toxicity, and embryonic lethality. J Biol Chem 281(9):5916-5927 https://doi.org/10.1074/ jbc.M511982200

17. Parveen S, Chen B, Liu L, Tan T (2017) Enzymatic phosphorylation of mannose by glucomannokinase from Mycobacterium phlei using inorganic 
polyphosphate. Enzyme Microb Technol 104:16-21 https://doi.org/10.1016/j. enzmictec.2017.05.006

18. de la Fuente M, Peñas PF, Sols A (1986) Mechanism of mannose toxicity. Biochem Biophys Res Commun 140(1):51-55 https://doi.org/10.1016/0006291x(86)91056-9

19. Reuter S, Gupta SC, Chaturvedi MM, Agganwal BB (2010). Oxidative stress, inflammation, and cancer: how are they linked? Free Radic Biol Med 49(11) 1603-1616 https://doi.org/10.1016/j.freeradbiomed.2010.09.006

20. Gonzalez PS, O'Prey J, Cardaci S et al (2018) Mannose impairs tumour growth and enhances chemotherapy. Nature 563:719-723 https://doi.org/ 10.1038/s41586-018-0729-3

21. Domenici L, Monti M, Bracchi C, Giorgini M, Colagiovanni V, Muzii L, Panici PB (2016) D-mannose: a promising support for acute urinary tract infections in women. A pilot study. Eur Rev Med Pharmacol Sci 20(13):2920-2925

22. Ofek I, Mosek A, Sharon N (1981) Mannose-specific adherence of Escherichia coli freshly excreted in the urine of patients with urinary tract infections, and of isolates subcultured from the infected urine. Infect Immun 34(3): 708-711

23. El-Mosalamy H, Salman TM, Ashmawey AM, Osama N (2012) Role of chronic E. coli infection in the process of bladder cancer- an experimental study. Infect Agent Cancer 7(1):19 https://doi.org/10.1186/1750-9378-7-19

24. Liu T, Zhang L, Joo D, Sun SC (2017) NF-KB signaling in inflammation. Sig Transduct Target Ther 2:17023 https://doi.org/10.1038/sigtrans.2017.23

25. Bloemer J, Bhattacharya S, Amin R, Suppiramaniam V (2013). Chapter Thirteen - Impaired insulin signaling and mechanisms of memory loss. Prog Mol Biol Transl Sci 121(2014):413-449 https://doi.org/10.1016/B978-0-12800101-1.00013-2

26. El-Far A H (2016) The role of receptors for advanced glycation end product in pancreatic carcinogenesis. Pancreat Disord Ther 6(1):1000166 https://doi. org/10.4172/2165-7092.1000166

27. Abe R, Shimizu T, Sugawara H, Watanabe H, Nakamura H, Choei H, Sasaki N, Yamagishi S, Shimizu H, Takeuchi M (2004) Regulation of human melanoma growth and metastasis by age-age receptor interactions. J Invest Dermatol 122(2):461-467 https://doi.org/10.1046/j.0022-202X.2004.22218.x

28. Gill V, Kumar V, Singh K, Kumar A, Kim JJ (2019) Advanced glycation end products (AGEs) may be a striking link between modern diet and health. Biomolecules 9(12):888 https://doi.org/10.3390/biom9120888

\section{Publisher's Note}

Springer Nature remains neutral with regard to jurisdictional claims in published maps and institutional affiliations.

\section{Submit your manuscript to a SpringerOpen ${ }^{\circ}$ journal and benefit from:}

- Convenient online submission

- Rigorous peer review

- Open access: articles freely available online

- High visibility within the field

- Retaining the copyright to your article

Submit your next manuscript at $\boldsymbol{\nabla}$ springeropen.com 